\title{
Venture Investment in The Small Entrepreneur Companies
}

\author{
Sajjad Mahmoud Babouei ${ }^{1}$, Ali Banej Shafiei ${ }^{2}$ \\ ${ }^{1}$ M.A student of accounting, Tabarestan non-profit institution of higher education, Chalous, \\ I.R. Iran, Email: sajjad_mahmoudiii@yahoo.com
}

${ }^{2}$ Instructor of Islamic Azad university, Faculty of Management and Accounting, Islamic Azad university, Chalous, I.R. Iran, Email: ali_banej@yahoo.com

\section{ARTICLE INFO}

Keywords:

Venture investment

Small Business

Entrepreneur

\begin{abstract}
Since one of the major problems for entrepreneurs to create and register small companies and their inventions is the lack of support of managers to drive them into venture investments, which is one of the ways of financing companies. Therefore, in this research, we have tried to find ways to solve and Review these problems. In this study, the stages of growth and development, innovation characteristics, specific problems of financing small enterprises, venture investments, risk capital outflows, types of investments, venture investment process and the main indicators of venture investments have been discussed. The result of this study showed that the government, the levers of financial encouragement, taxes, intellectual property, labor law, experienced and trained managers, the rules governing the activities of banks, insurance companies and retirement funds, the motivation for wealth creation and networking have a significant role in Encouraging small entrepreneurs to invest in risk.
\end{abstract}

\section{Introduction}

Entrepreneurship is the process of job creation and profit from the valuable combination of resources. An entrepreneur refers to someone who undertakes to organize, manage, and accept the risks of an economic activity. Entrepreneurs are individuals, groups or people who set up and run a new business, at least for more than one person. The complexity and growing competition in today's world has led to entrepreneurship as a driving force in growth and organizations. Because it can lead to countries' economic growth and development, productivity growth, employment creation and social welfare. Meanwhile, getting the funds needed to run businesses has always been a challenge for entrepreneurs. Some experts believe that: "The size of the business and its size are the most important indicator of banks' valuation, as bank managers prefer larger businesses to smaller businesses for investment" (Hanifi, 2013). Successful entrepreneurs must have the skills to get the funds they need, without sufficient funding, small businesses will never succeed. Lack of investment is a major factor in the failure of many businesses. Capital is an important and influential factor in economic growth patterns. Given the diversity of businesses and their business environments, there have been many innovations in entrepreneurship financing around the world that rely largely on nongovernmental resources and high levels of people's communities (Ramazanpour Nargessi

* Corresponding author at M.A student of accounting, Tabarestan non-profit institution of higher education, Chalous, I.R. Iran, Email: sajjad_mahmoudiii@yahoo.com

2538-8053/ @ 2018 IJARME. All rights reserved. 
and Ghaffari, 2015). Obviously, given the high volume of working capital required by the economic activists of the banking system alone, they cannot provide capital. Here, the role of new forms of financing in the form of capital participation is important the working capital required by the economic activists of the banking system alone cannot provide the required capital. Here, the role of new forms of financing in the form of capital participation is important. The engine of the advancement of technology is the creative ideas that are emerging in the minds of inventors and innovators and are followed by serious entrepreneurs in the form of a new business (Khalil, 2002).

But the majority of these entrepreneurs are young and hard-working engineers who lack the two main factors of success in the competitive market, namely, managerial knowledge and experience, and sufficient financial resources. So many attempts to launch new businesses have failed due to this. The key to solving this problem is in the hands of investors who are actively involved with entrepreneurs by relying on their excellent skills and with the adoption of calculated risks, and they cover their weaknesses with the goal of generating profits. Regarding this issue, the strategic and important position of these individuals, known as venture investors, can be easily recognized in the economy and accelerated the development of technology in the countries. For this reason, during risky timelines in developed countries, they have become one of the main chains of their national innovation system (Harrison \& Mason, 1996). Unfortunately, in Iran there is not only a record of the presence and activity of such investors, but the familiarity of managers and academics with the concept of venture investment is limited. Of course, efforts have recently been made to set up venture capital funds in the country that can be promising. However, to avoid this route based on a timely and uncertain test and error approach, informed policy making and intelligent drawing of the prosperous industry of venture investment in the country are required (Lamei, 2002). These species are designed and implemented as new and effective means of financing entrepreneurial projects and developing productive businesses and sustainable employment in different countries, taking into account the economic and social characteristics of those countries. One of these methods of financing is venture investment, which is also called venture and private investment. Investing in entrepreneurial venture business is one of the areas that, despite its importance and necessity, has been dealt with less (Nuechterlain, 2008).

This research addresses the role and place of venture capital investment and the importance that this type of investment has in financing small firms and entrepreneurial entities in today's changing environments.

\section{Theoretical Foundations of Research}

In this study, Gnyawali \& Fogol (1994) has introduced four main environmental elements that have a more weakening effect on the process of creating new firms, one of the most important elements of the economic and social conditions that tends to Investing for entrepreneurs. Government approaches and policies, economic and social conditions, job skills and entrepreneurship, financial and non-financial support. All of these factors have a direct relationship with the creation of new companies. In Joseph Schumpeter's view, entrepreneurs employ new employees, pay more shares to their shareholders, and increase their purchasing power from suppliers. As a result, new wealth is created through new demand, and new and old wealth is distributed between entrepreneurs and employees, shareholders and suppliers. He believes that entrepreneurs will bring innovations to the market, which will create new demand. This means that entrepreneurs are the main elements of creating and distributing wealth (Pourdariyani, 2001). The first source that entrepreneurs refer to in order to cover the funds needed to start a business is private resources. Entrepreneurs appear to have seen selfsufficiency, so that the most common source of funding for small businesses is provided from the private entrepreneurs' fund. For this group, risk and efficiency calculations, like other 
groups, are not the first priority (Bigdelu, 2004). After spending personal funds, the entrepreneur turns to friends and relatives who may be willing to invest in their business because of their relationship with the entrepreneur (Zimerrer \& et al., 1996). Randoy and Goel reviewed financial flows through personal finances against capital financing (stocks), and concluded that financing was more efficient by personal financial resources (Randoy \& Goel, 2003). Paulson \& Townsend, with research into Thai entrepreneurship, has concluded that financial pressures play an important role in shaping the entrepreneurial pattern in Thailand. The wealthy families are more interested in business creation and investment in business, and less in the face of financial pressures. Our pressures the rich are more interested in creating business and also investing in business, and they are less likely to face financial pressures. Financial pressures create more restrictions for entrepreneurial activities in the poorer areas of Southeast Thailand compared to the developed central regions (Paulson \& Townsend, 2003) and in a study on the effects of family ownership and management of US SME capital. In this research, he showed that family ownership has a number of disadvantages in addition to benefits, and also finds that family financing and public financing, in other words, the supply of shares to the general public separately affect SMEs. And these two categories of financing separately affect the net assets of the firm (Wu, 2006).

A business, in turn, has the capacity to generate capital by itself. This funding is available to any small company (Bigdelu, 2004). A small business can be used to finance corporate receivables, use of credit cards, accumulated profits, and leases on condition that they have the required financial resources. In the later phases of financing, such as the growth stage, companies can of the domestic source of accumulated profits to finance them. This source can be considered one of the least costly sources of finance that is used to meet the long-term needs and development of the company. Some entrepreneurs, if they find financial resources Disappointed from other locations, their companies with Using the most distressed source of finance, this source is their own personal credit cards. By putting start-up costs and setting up a company on credit cards, entrepreneurs must pay more than any other source of annual interest payments in Consider that this source is expensive and risky. However, some entrepreneurs will not be able to take another option (Zimerrer \& et al, 1996).

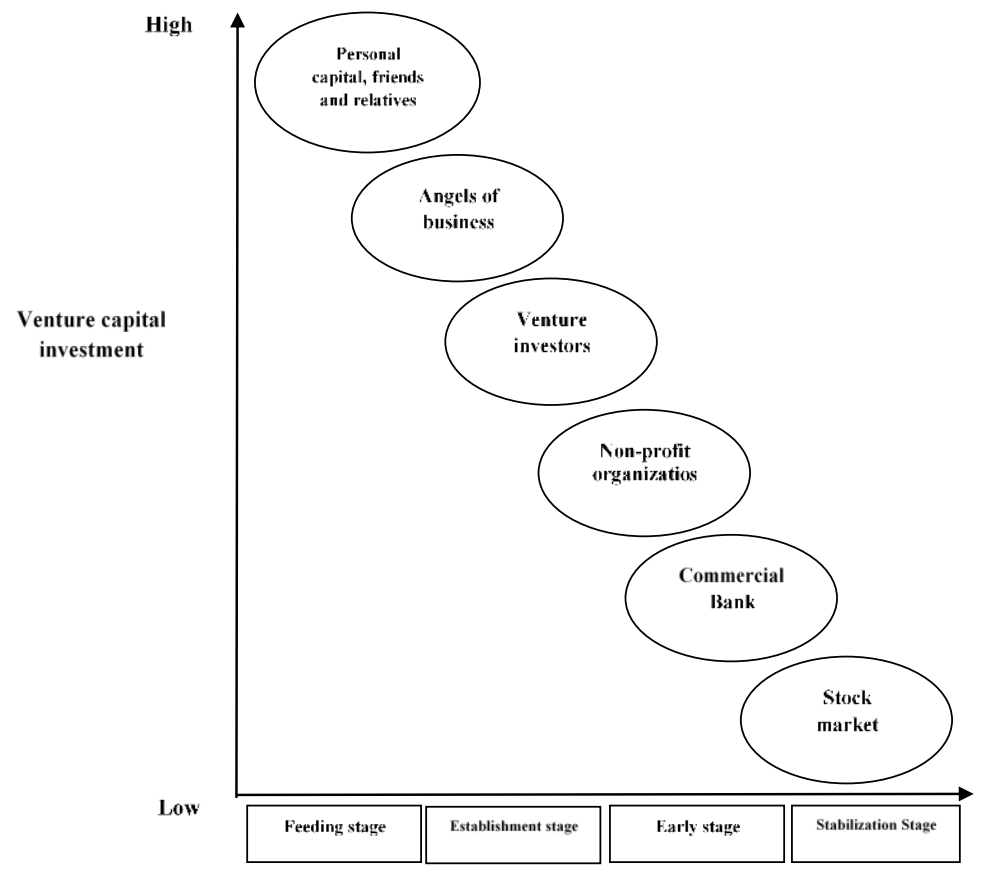

Chart 1- Stages of growth and the development of an entrepreneurial company 
As you can see in Chart 1, this chart consists of two dimensions: the investment risk on the vertical axis, which includes two large and small, and the stages of growth and development of entrepreneurial companies on a horizontal axis that consists of four stages. These four steps are, respectively, the feeding stage, the stage of establishment, the initial stage and the stabilization stage. When the company successfully completed its first stage of the nutrition phase with its financial support and relatives and close friends, the second phase, the phase, is established. The first people entrepreneurs can go to get material support is business angels. In other words, this group is suitable for the provision of capital and comes with the help of entrepreneurs. This hierarchy will continue until the last stage, the stabilization stage, which can only count on the financial support of commercial banks if the riskiness of the company is at its lowest level and has enough income and assets. (Pourdariyani, 2001).

\section{Features of Innovation in Small Businesses}

Table 1- Advantages and difficulties large and small companies in the field of innovation (the sentences within the parenthesis show the main features), (Country Assessment Organization, 2002)

\begin{tabular}{|c|c|c|}
\hline & Small companies & Large Companies \\
\hline Marketing & $\begin{array}{l}\text { The ability to react quickly to } \\
\text { market needs (Access to foreign } \\
\text { markets is very cost effective) }\end{array}$ & $\begin{array}{l}\text { Broadcasting and distribution } \\
\text { facilities, The ability to capture } \\
\text { market power by using the } \\
\text { products available }\end{array}$ \\
\hline Management & $\begin{array}{l}\text { The lack of bureaucracy, dynamic } \\
\text { entrepreneurship, and the rapid } \\
\text { use of new opportunities and risk } \\
\text { decision-making (Most of these } \\
\text { companies do not have } \\
\text { management professionals such as } \\
\text { business leaders, marketing } \\
\text { directors, and financial managers) }\end{array}$ & $\begin{array}{c}\text { Professional managers are able } \\
\text { to manage complex } \\
\text { organizations and develop } \\
\text { strategic plans for the company } \\
\text { (The excessive bureaucracy that } \\
\text { the accountants control and } \\
\text { control is the risk of it. } \\
\text { Managers may not have the } \\
\text { necessary dynamics for new } \\
\text { opportunities.) }\end{array}$ \\
\hline $\begin{array}{c}\text { Internal } \\
\text { communication }\end{array}$ & $\begin{array}{l}\text { The existence of efficient, } \\
\text { informal internal communication } \\
\text { networks increases the possibility } \\
\text { of rapid reaction in the event of } \\
\text { internal problems, and can bring } \\
\text { about rapid organizational } \\
\text { renewal and adaptation to the } \\
\text { external environment in these } \\
\text { companies }\end{array}$ & $\begin{array}{l}\text { (Internal communication is } \\
\text { often done to respond to foreign } \\
\text { threats and opportunities.) }\end{array}$ \\
\hline $\begin{array}{l}\text { Technically } \\
\text { qualified } \\
\text { manpower }\end{array}$ & $\begin{array}{l}\text { (The most of lacking human } \\
\text { resources and cannot adequately } \\
\text { support large research projects.) }\end{array}$ & $\begin{array}{l}\text { Ability to recruit qualified } \\
\text { technical personnel and the } \\
\text { ability to establish large } \\
\text { research laboratories }\end{array}$ \\
\hline $\begin{array}{c}\text { external } \\
\text { communication }\end{array}$ & $\begin{array}{l}\text { (Lack of time and resources to } \\
\text { identify and use the resources of } \\
\text { scientific and technological } \\
\text { expertise.) }\end{array}$ & $\begin{array}{l}\text { Ability to communicate with } \\
\text { scientific and technological } \\
\text { resources. The ability to create a } \\
\text { library and information service } \\
\text { and transfer research as part of a } \\
\text { contract to specialized centers }\end{array}$ \\
\hline
\end{tabular}




\begin{tabular}{|c|c|c|}
\hline & & $\begin{array}{l}\text { and the ability to purchase } \\
\text { technology and information } \\
\text { technology }\end{array}$ \\
\hline Financial & $\begin{array}{l}\text { (Serious problems in attracting } \\
\text { capital, especially risky ones, } \\
\text { innovation, there is a high } \\
\text { financial risk, the inability to } \\
\text { distribute the risk to a set of } \\
\text { projects.) }\end{array}$ & $\begin{array}{l}\text { Ability to attract market capital, } \\
\text { risk distribution ability on a set } \\
\text { of projects, the ability to } \\
\text { diversify and finance it, and } \\
\text { entry into new markets }\end{array}$ \\
\hline $\begin{array}{l}\text { Saving due to } \\
\text { scale and variety }\end{array}$ & $\begin{array}{l}\text { In some cases, scale savings result } \\
\text { in barriers to entry for small } \\
\text { companies. Inability to create and } \\
\text { maintain a production line or } \\
\text { integrated system }\end{array}$ & $\begin{array}{l}\text { Scale saving in production and } \\
\text { marketing. The ability to } \\
\text { provide complementary } \\
\text { products and to bid on key } \\
\text { projects in hand }\end{array}$ \\
\hline Growth & $\begin{array}{l}\text { (The possibility of dealing with } \\
\text { the problem of attracting foreign } \\
\text { capital necessary for rapid growth, } \\
\text { the probability of the failure of } \\
\text { entrepreneurial managers in the } \\
\text { management of complex } \\
\text { organizations) }\end{array}$ & $\begin{array}{l}\text { Product Development Capacity } \\
\text { and Growth Budget by } \\
\text { Developing Variety and } \\
\text { Purchasing Other Companies }\end{array}$ \\
\hline Legal rights & $\begin{array}{l}\text { (Inability to associate with the } \\
\text { intellectual property rights system } \\
\text { and the inability to spend time and } \\
\text { money on intellectual property } \\
\text { rights lawsuits) }\end{array}$ & $\begin{array}{l}\text { Access to legal professionals } \\
\text { able to defend intellectual } \\
\text { property rights in intellectual } \\
\text { property violations }\end{array}$ \\
\hline $\begin{array}{l}\text { governmental } \\
\text { laws }\end{array}$ & $\begin{array}{l}\text { (Failure to comply with } \\
\text { complicated rules) }\end{array}$ & $\begin{array}{l}\text { The ability to finance legal } \\
\text { services on complex laws }\end{array}$ \\
\hline
\end{tabular}

\section{Specific Problems of Financing Small Companies}

The comparative table 1 illustrates the particular problems of small companies to finance their activities: Performance changes for small firms are much larger than large firms, so that the growth rate and innovation stability will increase as company grows. This is one of the reasons for the increasing variety of products and the consequent increase in the number of customers of large companies. As a result, small companies are sensitive to unwanted changes in their environment. However, the likelihood of these changes is very high. The volume of demand for products, the turnover and the required costs are much higher than the capital base (primary) of small firms (in comparison with large companies). With regard to the various stages of development of companies, we conclude that the development of small companies is difficult, these changes, with many risks, change the various dimensions of companies. It is likely that investors prefer stable companies (at low risk) to these companies. Of course, this alone does not address the risks to the financing of small companies; it also increases the turnover (liquidity) and the probability of a failure of these companies. On the other hand, successful innovation companies are also faced with an abrupt (and relatively high) rise in demand and production requirements, which is also causing great problems for the expansion of the company. As has been said, there is a high risk of non-payment of small companies' debts due to the high ratio of innovative project costs to the basic capital of small firms, as well as the frailty and leaky growth of these companies. In addition, small companies have a small management system, and in many cases they only own a company in management. This feature 
means that small companies have a few or only one person with the power of thinking and management, which will also be sensitive to unwanted management changes.

On the other hand, investors often emphasize the competence of management when considering innovative projects. The need for the development of small companies, the creative environment, strong management and the ability to create organizational changes in a new environment. It is possible to promote new and innovative thoughts in order to maintain competitive power and growth of the company. When paying a loan, banks must pay for costs such as investigation, tracking and follow-up, so making large loans more affordable for banks. So small companies are in the next priority. Another reason is the limited bargaining power of small companies when negotiating with the bank, which forces small firms to only go on projects with higher profitability (compared to larger corporate projects). This will take the opportunity of many projects (in different sectors of the industry) from small companies. It's a fact that some small companies, because they need more profit, knowingly choose hazardous projects and thus cause many problems for themselves. Small companies are not all the same and differ on some points. This causes financial inspectors of banks or other investors not to be able to deal with a well-established, well-established system of ongoing assessment and evaluation of small companies. Another problem with financing innovation in small companies is due to the heterogeneity of borrower and borrower capabilities. On the one hand, companies (especially small companies) have little knowledge of the financing methods, focusing more on the technical issues of their plans, and less of their financial management, while financial decision-makers examine the technical knowledge that lies in the design and In general, this kind of technical information (as an indicator for evaluating the project) is not worthy of attention, and their emphasis is on previous financial statements, financial position, budget, and liquidity forecasting (in other words, financial management of projects). Therefore, the policy of large corporations based on financial management yes, uh These companies have separate finance departments that are more reliable than banks and financial institutions (The same, 2002).

\section{Venture capital investment}

Risk capital is a capital that, with management assistance, is provided to young, small, fastgrowing, and economically viable companies. Vulnerable capital is one of the major sources of financing for small and small businesses. Venture capital venture companies are most of the companies or co-operatives that finance their funds, retirement funds, foundations, corporations, wealthy, foreign investors or self-funders (Zacharakis \& Meyer, 2000). Venture capital firms do not seek to earn on-going income from their investments, and if the company is profitable, their profits will be earned by selling their shareholding. As the result of innovative and innovative activities is so uncertain, banks often reluctantly Fewer investors to invest in; hence, an entrepreneur who does not have enough capital to implement his plan, and the success of the plan has relative reliance on the risk capital market. Participating in venture capital investment companies The only funding is limited, but also continued to provide support and advice as well. Also, these companies have operational and operational roles, and, as other owners, are at stake in companies, they have close coordination with their goals. Venture capitalists carefully consider their technical and commercial merit while reviewing proposed companies for investment. These investors invest in a small fraction of the companies they are investing in, and they take a long time to reach the goals of the companies (Gnyawali \& Fogol, 1994).

They sometimes make joint ventures with other venture capital investment firms. For decades, venture capitalists, with the support of small, entrepreneurial and technological companies, have played a significant role in creating job opportunities, economic growth and increased international competitiveness. Venture capital firms may be small or run large corporations with more than one billion capitals. Some venture capital firms have been able to achieve 
significant success by creating synergies between the various companies they have invested in. For example, there is a good relationship between a company with significant software products but no proper distribution technology, with another company with superior distribution technology (and both in the investment portfolio of a venture capital investment firm). Venture capitalists help grow companies, but try to get out of their investment for a maximum of three to seven years. Investments that take place in the early stages of the company's life cycle require seven to ten years to be profitable. While investing in the next steps usually takes much less time. Therefore, the waiting time for the return on capital is proportional to the position of the capitalist company in the development cycle. The venture capital is neither short-term nor easily criticized. Therefore, you must take specialty, seriousness and care. Venture capital firms, depending on their nature and strategy, will seek to exit after three to seven years from the time of the first investment. Although the initial supply of stock in the stock market is the most attractive and most outrageous exit mechanism for venture investors and corporate owners, the most successful outflows come from mergers or the purchase of the company from its main founders or other companies. The investment firm's expertise in successful exit from investing is the determining factor in its success. Therefore, one of the important issues for investors, the time and form of withdrawal from investing and how to collect funds from the recovery of capital. Investors are only willing to participate and inject funds, which risks their participation with good returns. The existence of an appropriate exit mechanism is an essential and essential tool to ensure that the market function of the risk capital market is guaranteed. An appropriate mechanism for companies, especially for young, dynamic and profitable companies (as mentioned above), is the initial supply of stock in the stock market. Another way out is the sale of the Entrepreneur to larger companies. Of course, in mature companies with generous production and liquidity, entrepreneurs can directly buy the share of venture capital companies and take full control of the company and maintain it. Another way is to hold a bidding, which in this way sells the investment company that owns the entrepreneur to the highest bidder. The following table shows the ways out of venture capital investment (Muzyka Birley \& Leleux, 1996).

\section{Types of Venture Investment}

\section{Special or non-specialized venture investment}

Some boxes have different functions and in different industries such as semiconductors, software and more. . . Invest in. But some do invest in just one technology or industry. The choice of specialized or non-specialized activities depends on the capabilities of the staff and managers of these funds and their investment strategy.

\section{Centralized or decentralized investment}

Funds activity is also different in terms of geographical concentration. The activity of some boxes is concentrated in one city, province or country, but some of the boxes are free of any geographical constraints. Certainly, the choice of centralized or decentralized activities depends on the capabilities of these funds and their investment strategy.

\section{Officially venture investment}

Vulnerable investment funds, or investment firms (official sources of risk capital), or wealthy people (unofficial venture capital or trade angels), as there is usually a good familiarity with the activity or activity of professional venture investment ventures, henceforth, only Corporate venture capital investment (as one of the types of venture capital investment), official venture investment is divided into two categories: direct and indirect. In the first instance, companies and official sources are drunk and immediately looked at the investment company are invested, while the second case, investing through an intermediary) financial institutions or venture capital funds) falls. 


\section{Informal Venture Investment}

In addition to officially risk-based investments, there is a more limited market that complements it and is called informal risk capital. Of course, the word (market) may be misleading because most agreements of informal venture investors do not form in the market and are more likely to be followed through individual calls. An informal venture capital market, including real people (usually referred to as informal investors, business angels or independent investors) that provides the capital directly to new and growing businesses that have not previously collaborated with them. (Harrison \& Mason, 1996).

Genuine Risk Capital: It emphasizes the early stages of corporate growth, service and investment assistance with more patience. Typically, these funds inflate entrepreneurial skills with a high added value to the formation of corporations and are more likely to be provided through informal venture capital.

Hazardous Market Capital: More than the formal investment institutions, it focuses on investment in the downstream stages, and includes a shorter horizon. In some countries, venture investments have been driven from genuine to market.

\section{The venture investment process}

We need to know that the process of providing risky financial resources and the relationship between entrepreneurs and venture capitalists is very long and long. If someone follows a quick rule and imagines that he can quickly agree with a venture capitalist and solve his financial problem, he will be very surprised in the face of reality. Some venture investors may come into action quickly, but their number is very low. Instead, most of them carry out full-scale reviews and evaluations to make sure they have found a good investment. Then they make a long-term investment. These investors need a long-term review period. Therefore, only a very small number of venture capital investors operate in the short term (Gladstone, 2002).

\section{Main Indicators of Venture Capital \\ 1- Participation in the management of companies}

It should not be assumed that the role of venture capitalists in financing the financial resources is reduced, and they will have a reactive position relative to the performance of their capital companies. Because of the partnership in the ownership of the emerging companies, these investors are committed to their success and are making the most of their efforts to increase the profitability of their investment through the success of their portfolio companies. Ironically, they also have the capabilities necessary for such assistance. These investors, who are mostly experienced and highly trained, are actively involved in this field by relying on experiences gained from helping similar companies. The personal and organizational connections of these investors are, in most cases, the gateway to emerging companies, because the management of startups is more of a technical entrepreneurship (those who do not have sufficient managerial experience (strategic marketing and planning) are among the other areas where these investors are very Therefore, venture capitalists are valued by investing in the management of emerging investment companies, and their entrepreneurial role is more significant than the role of providing financial resources. Basically, one of the reasons for the importance of the head The risk of economic growth in the countries is also the same. This means that young entrepreneurs who do not have managerial skills are assisted in this way, which is why, in countries that have recognized the importance of such investments, one of the members of the investment funds in the board of directors Investor corporations will come to provide them with more value for money.

\section{2- Management assessment}

As defined in the definition of risky sources of finance, these resources are invested in young and emerging companies that are fast growing and inherently becoming important economic units. But the discovery of this inherent power is by no means easy. Because these companies 
may be in stages that still do not have any actual products or enterprise organizations. For this reason, such investments are at high risk. Therefore, it is necessary to make very precise assessments of such companies in the first stages, which, of course, are not limited to economic and technical evaluations (sanobar, 2001).

\section{Managerial characteristics of the investment}

Integrity and honesty: The criterion employed by each investor is to test honesty and integrity of management. If the Entrepreneur Group is not honest, it is unlikely that the creditor or investor will invest in it.

Experience: Every creditor and investor tends to benefit from entrepreneurship that has the most experience in the field.

Success: Successful successes in the history of entrepreneurial activity are a big sign. Every investment should be successful. If an individual entrepreneur succeeds, his chance of success will increase significantly. We should be careful about the entrepreneurial background. What did he get at the university? How about work? Successful people make the world change. Therefore, here is an important lesson here that is to be betrayed to successful people because they always have a spark that illuminates the fire. They want to be winners. They have succeeded in the past, and the likelihood of success in the future is high.

High energy: What most investors need to look for in a management group is high energy. Entrepreneurship is unbelievable. The entrepreneur should be the person who takes hours of hard work. Because the need to do a great job is one percent inspiration and 99 percent diligence. Therefore, the entrepreneur must be a healthy person, mentally prepared. His health is measured when he is faced with daily physical excitement and physical exertion. The investor must make sure that the entrepreneur or manager is a strong person and energy-rich. He must have enough energy to succeed. Good management is not only capable of doing work in a matter of hours, but also of his work together with success.

Motivation: Many entrepreneurs work long hours during the week to generate income. So when it comes to asking an entrepreneur why you're doing all this, while you know these things fill most of your life, why do you want to be involved in this situation? The false answer to this question is that the entrepreneur says: I want to be my boss, the president does not understand me, I want to work for myself, and answers like that) because investors are not responsible for solving personal or mental problems of entrepreneurs (while the answer is It is appropriate that this is a good opportunity for me and for someone to make an investment because it can make a lot of money this way. Of course, the greedy people who want to earn a lot of money are not few. But experience has shown that winning people usually but business profits are a way of measuring one's success. Every person has standards for evaluation - for example, a doctor's measure is to succeed, save the lives of patients, or recover. An inventor with his inventive utility, success when a person deals with business, sales and profits are the ultimate criterion for success. Investors must also seek entrepreneurship that measures success with profits.

Age: Venture capitalists believe that entrepreneurs should be between thirty to forty-five. The venture investors of this fifteen-year period consider humanity as the best era of entrepreneurship. Usually, the age below the age of thirty means that the entrepreneur does not have the management experience or knowledge necessary to advance the affairs of a growing company. At the age of forty-five years old, the entrepreneur is experienced, but lacking in motivation. Obviously, this rule has exceptions, and these are considered in the investigations of venture capitalists (Abbot \& Hay, 1995).

\section{Conclusion}

The set of commercial laws of each country is the basis for business and investment activities in that country, and has a great impact on the type, scope and efficiency of these activities. Venture capital investment, as one of the types of economic and business activities, affects 
these rules. In fact, the venture capital industry is developing and developing under the umbrella of commercial law. The appropriate legal framework has brought about the success and prosperity of this industry and the growth of small entrepreneurship. The government can influence two ways in terms of entrepreneurship and the encouragement of entrepreneurial activities, one by the rule of law and regulation, such as the issuance of various licenses that regulate economic and social relations. The rules that are in place here are barriers to entry, growth and barriers to exit. The problem of leaving the business will reduce the attractiveness of entry, and the government can remove barriers by eliminating waste regulations. On the other hand, the government can play an important supportive role for entrepreneurs. Because entrepreneurs usually start with small businesses. Another important role of the government in supporting and developing venture investments and entrepreneurship is the encouragement and financial support of venture entrepreneurs and investors. With the encouragement of small, novice and venture capital firms, the government can encourage new startups in less developed regions, and thus increase the speed of technological development in the country and create jobs. By reducing the tax rate on investment profits, the government can help boost entrepreneurship and create new manufacturing and service firms, as well as boost the venture capital industry. The tax rate for companies compared to businesses is set to encourage people and investors to set up companies.

Also, the government can make sure that entrepreneurs begin to reduce their initial costs for the creation of an innovation and invention, which will generate some of the benefits that their invention brings to the community in the form of profits. The patent, the right to publish, and so on, are legal mechanisms that are limited to creative entrepreneurs for a limited period of time, give them exclusive power to withdraw their work. Also, venture capital investment activities, like other economic activities, require highly skilled and well-managed managers, but in addition to general management knowledge, there is also a need for other expertise and expertise to manage venture investment. Managers who enter this field must have sufficient expertise, experience and knowledge in order to succeed. These managers should be trained in the areas of entrepreneurship, investment and finance management, risk management, economic activity, which they are managing. Other support that the government can offer from small entrepreneurs include the correction of the rules governing the activities of banks, insurance companies and retirement funds, the motivation for wealth creation and networking. In general, the performance of the financial technology development funds of the country showed well that the facilities of these funds did not in any way correspond to the concept of venture investment, and that is why the financing of the small entrepreneurs of the country is facing serious problems and young entrepreneurs in promoting the trade and supply of ideas The innovative ones on the market are deprived of risk management ventures. This bitter truth is a sign of a serious vacuum in the national innovation system of the country and a warning for the future of the technology development process (especially in the advanced industries of the country). On the other hand, the infrastructure of development of the investment-oriented investment industry is not available in the country. Most importantly, this issue has not been sufficiently important for policy makers of the National Iranian Innovation System (which is more than their unfamiliarity with the various dimensions and effects of venture capital investment), resulting in no coherent and targeted plan for promoting the venture investment industry and no pears.

\section{References}

Bigdelu, Mehdi, (2004), Study of Various Resources of Entrepreneurs' Financing, Proceedings of the First National Conference of the Risk Investment Industry, Tehran: Tehran University of Management. 
Education Assessment Organization, (2002), Entrepreneurship, Publications of the Secretariat of the Entrepreneurship Development Program at Universities.

Gladstone D., Gladstone L., (2002), Venture Capital Handbook, Prentice Hall.

Gnyawali, D. and Fogol, D. (1994), Environments for Entrepreneurship Development: Key Impressions and Research Implications, Entrepreneurship Theory and Practice, Baylor University.

Hanifi, Farhad (2013), Venture Capital of Structures and Functions, Journal of Tehran Stock Exchange, No. 21.

Harrison, R.T., and C.M. Mason (1996), "Developing the Informal Venture Capital Market: A Review of the Department of Trade and Industry's Informal Investment Demonstrating Projects", Regional Studies, Vol. 30.8

Khalil, Tariq, (2002), Technology Management; The Key to Succeeding in Competition and the Creation of Wealth; Translated by Seyyed Kamran, Bagheri and Mahoor Mellatprast; Text Message Publishing.

Lamei, Behzad, (2002), The Legal Constraints of Entrepreneurship Growth in Small Industries of Iran, Journal of Work and Society, No. 45, Shahrivar.

Muzyka, D. and Birley, S and Leleux, B. (1996). Trade-offs in the investment decisions of European venture capitalists, Journal of Business Ventures, Vol. 11, No 4

Nuechterlein, Jeffery, (2008), International Venture Capital: The Role of Startup Financing in the United States, Europe and Asia, Council on Foreign Relation \& Westview Press.

Paulson, A. \& Townsend, R., (2003), entrepreneurship and financial constraints in Thailand, journal of corporate finance, 10 (4), pp.229-262.

Pourdaryiani, Ahmad (2001), Entrepreneurship-Definitions-Theories-Patterns, Tehran, Pardis Company, Third Edition, Summer.

Ramezanpour Nargesi, Qasem, Ramezanpour Nargesi, Somayeh and Ghaffari, Ali (2015), The Key Factors Affecting the Development of Technology Entrepreneurship in Knowledge Companies Based on Science and Technology Parks in Iran, Journal of Entrepreneurship Development, Vol. 8, No. 4, Winter, P. 766-749.

Randoy, T. \& Goel, s. (2003), ownership structure, founder Leadership, and performance in Norwegian SME: implication for financing entrepreneurial opportunities, 18 (3), pp. 619637.

S. Abbott \& M. Hay, (1995), Investing for the Future: New Firm Financing in Germany, Japan, the UK and the USA. Pitman Publishing

Sanobar, Nasser (2001), Intellectual Property and Entrepreneurship: Concepts and Indicators of Iran, Entrepreneurship Conference and Advanced Technologies, October.

Wu, z., (2006), Effect of Family Ownership and Management on Small Business Equity Financing, Journal of Business Ventures, 22 (7), pp. 875-895.

Zacharakis, A. and Meyer, G. (2000), The potential of actuarial decision models: Can they improve the venture capital investment decision? Journal of Business venturing, No. 14

Zimmerer, W. Thomas dan Scarborough, Norman M., (1996), Entrepreneurship and the New Venture Formation. Upper Saddle River, N.J.: Prentice Hall. 